\title{
Green Project Assessment within the Advanced Innovative Development Concept
}

\author{
VIKTORIIA SHKOLA ${ }^{1}$, OLHA PROKOPENKO ${ }^{2}$, ANDRIY STOYKA ${ }^{3}$, VADYM NERSESOV ${ }^{4}$, \\ ALEKSANDER SAPIŃSKI ${ }^{5}$ \\ ${ }^{1}$ Department of International Economic Relations, SUMY STATE UNIVERSITY, SUMY, UKRAINE. \\ 2Department of Economics, COLLEGIUM MAZOVIA INNOVATIVE UNIVERSITY SIEDLCE, POLAND; TEADMUS OÜ, \\ TALLINN, ESTONIA. E-mail: info.teadmus@gmail.com \\ ${ }^{3}$ Department of Tourism, DONETSK STATE UNIVERSITY OF MANAGEMENT, MARIUPOL, UKRAINE. \\ ${ }^{4}$ Department of Computer Science, DONETSK STATE UNIVERSITY OF MANAGEMENT, MARIUPOL, UKRAINE. \\ ${ }^{5}$ Department of Law and Social Science, BIELSKO-BIAŁA SCHOOL OF FINANCES AND LAW, POLAND.
}

\begin{abstract}
Objective: The article's objective is to develop scientific and methodical grounds to assess the green project within the advanced innovative development concept to deliver EU Environmental policy.

Research Design \& Methods: The most relevant for our aim are the sustainable development concept and the advanced innovative development concept. We used a broad literature review.

Findings: The proposed approach is derived from the sustainable development concept and the advanced innovative development concept. It includes four types of projects: green projects, environmentally destructive projects, environmentally neutral projects, mixed ones. The sustainability index, recilience inxex, risks, including country risk, is calculated to enhance assessment accuracy.

Implications \& Recommendations: theoretical and methodic approach, improved by authors, to control innovative activity ecologization, based on $\mathrm{EECl}$ forecasts, allows stakeholders to reduce a risk of the innovative project and increase the assessment accuracy at its starting stages, enabling the increase of the strategic managerial decisions quality and, thereby, the environmental and economic security of stakeholders.

Contribution \& Value Added: The connection of three perspectives - economic, environmental and social - will capture the complexities of project management-oriented to advanced innovative development within the concept of sustainable development.
\end{abstract}

Keywords: innovation, sustainability index, advanced development, green project

JEL Classification: D81, 022, 033

Received: 25 April 2021

Accepted: 1 ,May 2021 


\section{Introduction.}

Given that climate change is the greatest existential threat to humanity in an increasingly globalized world, Green transitions of the EU's and Ukraine's economies in the framework of the European Green Deal of 11 December 2019 (European Comition, 2019) is undebatable. The only factor in sustaining the economic growth is the innovative advance within the environmental framework (Marsh \& McLennan, 2020; Miśkiewicz \& Wolniak, 2020; Shkola \& Shcherbachenko, 2011).

According to the concept of sustainable development, companies engaged in innovation activity focus on the high economic efficiency of innovation and consider its environmental impact as one of the most important criteria for making investment decisions. In conditions of the economic crisis, the increasing globalization, changing market structure and business environment the fundamental principles and means of management is supposed to be developed (Kuzior et al., 2019; Dankeieva et al., 2021; Mikhno et al., 2021).

Moreover, ecological and economic analysis of innovative projects, including assessment of the company's internal potential, the level of its market opportunities within the cut-throat international competition, project risks in the international business environment, the level of project ecologization, is to be the critical indicator of the project feasibility, taking into account the impact on the environment during the ecological and economic cycle (EEC) of green innovation (Hutsaliuk et al., 2021).

Therefore, the object of the article is to develop scientific and methodic grounds to assess the green project within the advanced innovative development concept to deliver EU Environmental policy.

As its theoretical framework, it will use a combination of project management, risk management, theory of innovation and paradigm of sustainable development. Our study concerns an approach to the environmental and economic estimation of green investment projects in line with the assumptions of the advanced innovative development. In particular, we would like to highlight that the structure of its business portfolio defines the level of its environmental and economic safety.

The article is divided into four main parts. The first part (Literature Review) illustrates the existing theoretical and methodological approaches to evaluating innovation activities. The second part (Material and Method) describes the research methods and the methodological approach used. The third part (Theory Development) presents a scientific approach to environmental and economic investment project estimation based on the sustainability, recilience and risks assessment adopted within the advanced innovative development concept. The fourth part (Conclusion) summarises and discusses practical implications and further recommendations for advanced innovative development management to deliver EU Environmental policy.

\section{Literature review.}

Studying the existing theoretical and methodological approaches to the evaluation of innovation activities (Andreeva, 2006; Dzwigoł et. al., 2019), three fundamental approaches have been identified, namely:

1) the approach based on qualitative characteristics of innovation and its impact on the environment. It is used in quality management for improving the overall quality of the final product or service and imposes an assessment of technical performance indicators without taking into account economic value;

2) the approach based on the socially necessary labor costs. It used to determine the production cost as the consumer value and socially necessary labor costs to create new products;

3 ) the approach based on economic effect and efficiency (including statistical or simple assessment methods and discount methods) measured in monetary units. The main disadvantages are difficulties in calculating some indirect indicators and all possible effects of branching out the 
innovation.

It should be noted that the majority of indicators for evaluating innovation activities are related to measuring its economic performances. Indeed economic indicators are vital for decision-making, but the issuers of innovation project feasibility occur not only in the economic framework.

The studies (Kotenko et al., 2020; Kwilinski et al., 2019) give the opinion that it is crucial to take account of the ecological performance indicators of innovation (at least large-scale ones) because both society's and company's economic interests might be different for the following reasons:

- the damage to the environment far exceeds the company's financial capabilities to repair it;

- limited financial resources, which causes insufficient investment in projects and programs aimed at environmentally friendly innovations;

- imperfect ecological taxation mechanism resulted in a discrepancy between ecological and economic losses caused by the company's activity and compensation for damage to the environment in the form of budget revenue;

- lack of scientific knowledge to accurately assess the environmental repercussions of investment activities.

Klimenko (2011) points out that the environmental and economic evaluation of the project in contrast to the economic evaluation is to increase the objectivity of measuring efficiency in terms of prospects for sustainable development. Moreover, like Liu (2012) states, it is the ecological basis valued at natural capital that is the milestone of the circular economy. Furthermore, justification for green evaluation of eco-innovation is scrutinized by Luo et al. (2017). Economic assessment of the eco-constructive and eco-destructive impact of investment projects on the environment is one of the most critical factors in economic decision-making. Meanwhile, ecological and economic evaluation of investment activity, making up of its economic and environmental results, is one of the key high effective means of environmental protection because preventing negative consequences is much cheaper than compensating.

The issue of ecological and economic assessment of innovation project is assumed to be related to its environmental footprint estimation, which is regarded as an activity to identify, analyze, and consider the likely consequences of its environmental impact to decide upon embarking on the project. In the study (Andreeva, 2006), ecological and economic assessment characterizes the changes in economic activity performances in response to the innovative processes. Moreover, its primary function is informational. The main tasks are to most accurately indicate a connection between processes occurring in nature, society, and technical systems, using natural resources (Omelyanenko et.al., 2020).

Modern ecological and economic assessment methods are based mainly on the calculation of economic efficiency, ecological and economic efficiency, socio-ecological and economic efficiency.

According to neoclassical welfare economics, economic efficiency is regarded as producing the best or optimal combination of products through the most efficient combination of resources. From this perspective, the optimal output is understood as a combination of products, which would be opted by individual consumers on the perfect market in response to the price reflecting the real production costs. The effective combination of resources is thought to be one that enables the company to produce output at the lowest opportunity cost. In contrast, ecological and economic efficiency is the ratio between the economic benefits and losses of the investment project, including external ecological effects and social and economic consequences related to them (Klimenko, 2011). As it is explored by Prokopenko (2011b), depending on what results and costs are studied, the efficiency indicator meaning is changed (namely economic, ecological, and social).

Scholars (Dzwigot, H. et al., 2019) have considered the concept of social and economic efficiency as a judgment about the fulfillment of the internal and external functions of a state (namely national security, law and order, achieving social justice, increasing life expectancy and high quality of life). From this perspective, only at the macroeconomic level should social and economic efficiency is considered. 
Andreeva (2006), researching the concept of social efficiency, has suggested assessing the social, ecological, and economic efficiency of the investment project, including its direct results and costs and its external effects in related sectors. An assessment aims to obtain quantitative criteria for making decisions, ensure the choice of future economic activity with the lowest environmental and social costs, determine acceptable for social return on investment.

In the study (Prokopenko et al., 2015), the social, ecological, and economic efficiency of investment has been scrutinized as a critical factor encouraging investors to invest in green innovations. Furthermore, the authors' approach to estimation social, ecological, and economic efficiency and potential of ecologization motivation has been considered in developing international ecological policy to accelerate the rate of innovative activity ecologization, and thereby the level of national and international environmental security.

In work (Shkola et. al., 2021), the term of socio-ecological and economic efficiency is considered as a system of indicators making up the overall results and the overall costs of the environmentally friendly innovation development (accumulated for innovators, consumers, and society as a whole) throughout the EEC.

Furthermore, in practice the assessment of ecological and economic efficiency means the estimation of environmental damage. According to Klimenko (2011), nowadays, most investment projects are evaluated from their possible negative environmental impact. Additionally, it is necessary to consider the possible positive impact on the environment (or environmental construction). Moreover, economic loss resulted from environmental damage is regarded as the real and possible costs of economic entities due to ecological destruction (environmental damage) and additional costs to compensate for these costs.

Thus, it can be argued that the purpose of environmental and economic assessment is the inclusion of environmental aspects (environmental costs and benefits) in investment management. As has been noted above, to some extent do modern methods of investment analysis take into account the impact of society on the environment. In particular, both Life Cycle Assessment and Cost-Benefit Analysis allow stakeholders to consider the positive and negative externalities that can be valued (Gorgitano \& Pirilli 2016; Guo, 2018; Mayer, 2019; Motta et. al., 2018). It should be agreed with scholars (Klimenko, 2011; Kotenko et.al., 2020; Li, 2016) that the latter method is suitable for analyzing investment projects to assess the social effect. For the analysis of investment projects at the level of enterprises, this method is inappropriate.

The Environmental Impact Assessment methodology used in international practice allows stakeholders to predict the ecological destructive and constructive ecological results of innovation, as well as to assess its potential economic, environmental, and social impact, thereby reducing uncertainty at the feasibility stage of an investment project implementation (Li \& Ohkubo, 2016; Li et al., 2019; Linde, 2013). According to Convention (1991), Environmental Impact Assessment is a national procedure for assessing potential environmental impacts. The latter means any consequences of planned activities for the environment, including human health and safety, flora, fauna, soil, air, water, climate, landscape, historical monuments, and other tangible objects, and the consequences for cultural heritage or social and economic conditions. Experience has shown that the disadvantage of the Environmental Impact Assessment method is the extremely costliness of procedures related to its implementation. Furthermore, its implementation demands the processing of diverse databases (Enríquez-de-Salamanca, 2017; Li \& Ohkubo, 2016). Thus, despite its strengths (high accuracy of calculations, scientific validity), the disadvantages complicate the possibility of its widespread use in practice.

In the international practice of investment analysis, all methods are conventionally divided into statistical methods based on accounting estimates and methods based on discount estimates (Lipsits \& Kosov, 1996). It should be noted that these techniques are pretty widespread but also require value measurement of costs and results of innovation activities. Also, the reduced costs method, based on determining the costs required for environmental measures, is a criterion for deciding on 
costs that should be minimized.

Other techniques, based on the cash flows theory, involve the use of other decision-making criteria based on the comparison of results and costs, namely net present value (NPV), profitability index (PI), internal rate of return (IRR), payback period (PP) (Table 1).

Domestic and foreign scholars (Artyukhov \& Artyukhova, 2018; Artyukhov et. al., 2017; Artyukhov \& Ivaniia, 2017; Kurbatova, 2018; Kurbatova \& Khlyap, 2015; Popova \& Safyants, 2013) have adopted these methods to the needs of ecological and economic assessments of innovation, including the ecological components of benefits and costs of investment projects in the different branches of economy.

Besides, within the theory of innovation marketing (Prokopenko, 2011a; Prokopenko \& Shkola, 2012), the comprehensive assessment of innovation, including eco-friendly ones, are considered. It is based on determining the producer's economic efficiency (from the production and implementation of innovation) and the consumer's economic efficiency (from buying and applying innovations). In this case, the environmental component is assessed within the life cycle of innovation, mainly through the innovation's qualitative characteristics.

Each of the approaches mentioned above has practical value. Otherwise, the problem of the comprehensive ecological and economic evaluation of the green innovation to avoid the shortcomings of other methods and make scientifically justified decisions based on the comparability of the different indicators to the same unit of measurement has been unresolved. Moreover, due to the cut-throat international competition resulting from the global economy, it is crucial to consider the country's risks and level of innovation competitiveness.

\section{Material and Methods.}

This research has been carried out using a systematic literature review methodology, similar to reviews of innovation management, investment analysis, and portfolio management (Koval et al., 2020; Kurbatova, 2018; Liu, 2012; Luo et al., 2017; Mura et al., 2015; Tanashchuk et al., 2018). Qualitative meta-analysis methods have been utilized to extract, critically assess and synthesize the current sustainable development literature, including trends, drivers, and barriers and suggestions for future research (Brauweiler et. al., 2017; Kuzior et. al., 2019; Kwilinski et. al., 2019; Li \& Okhubo, 2016; Linde et. al., 2013). The review followed an iterative process; search terms were updated as the literature review progressed, and citations of articles were examined for potentially missed cases. The key selection criterion was any published scientific article or peer-reviewed conference proceedings that addressed sustainable, innovative development and applied an investment analysis model or innovative business case framework. This scope was further refined to a more specific criterion. The article discusses the methodology of assessing the innovation, including an eco-friendly one and specific costs and benefits for stakeholders from innovations in different branches of the economy. It was done to eliminate cases where innovation was mentioned as the object of engineering, but not the object of economics or environmental economics, for example, experimental studies on experimental-industrial samples discussed by Artyukhov \& Ivaniia (2017), Jay \& Morad (2020).

The searches were done between April 2018 and April 2020 in online scientific databases. The first search was done in Web of Science using the keywords "investment analysis" and "innovation", which resulted in more than 5000 articles, thirty of which were relevant. This initial search showed limited published sources. We expanded our search beyond Web of Science to Google Scholar to include conference proceedings and other sources that may not be available in Web of Science. Further searches have been conducted using the keywords "assessment" or "innovation" and "efficiency" and a variety of keywords, some with wildcards. The keywords used were 1) "benefits", 2) "costs", 3) "risk", 4) "management", 5) "project", 6) "evaluation", 7) "economic damage*" and 8) "environmental damage*". Next, we searched for 9) "ecological damage" and "country risk," and 
lastly we searched for 10) "assessment" AND "innovative" and "project", but found no additional cases that completely met our criteria.

Table 1. Advantages and disadvantages of methods of the ecological and an economic evaluation of efficiency

\begin{tabular}{|c|c|c|}
\hline Method & Strengths & Weaknesses \\
\hline NPV & $\begin{array}{l}\text { It allows stakeholders to rank the projects } \\
\text { reliably in order of their ecological and economic } \\
\text { performance; } \\
\text { Better than other methods does it show the } \\
\text { profitability of investment; } \\
\text { It allows investors to take into account the } \\
\text { environmental risk of the project; } \\
\text { It is pretty easy to apply; } \\
\text { It does not require significant costs for its use }\end{array}$ & $\begin{array}{l}\text { The results are highly dependent on the } \\
\text { discount rate; } \\
\text { It is inappropriate to compare projects in } \\
\text { case of equal net present value and different } \\
\text { investment simultaneously; } \\
\text { The results of the calculation are highly } \\
\text { contentious; } \\
\text { It does not take into account the scale factor } \\
\text { of projects }\end{array}$ \\
\hline PI & $\begin{array}{l}\text { It shows the profitability of the investment } \\
\text { project; } \\
\text { It allows investors to take into account the } \\
\text { environmental risk of the project; } \\
\text { It is pretty easy to apply; } \\
\text { It does not require significant costs for its use }\end{array}$ & $\begin{array}{l}\text { The meaning of return index does not always } \\
\text { correspond to net present value; } \\
\text { It is inappropriate to rank projects by the } \\
\text { level of profitability } \\
\text { The results are highly dependent on the } \\
\text { discount rate; }\end{array}$ \\
\hline IRR & $\begin{array}{l}\text { It ensures the independence of its results from } \\
\text { the amount of investment; } \\
\text { It is appropriate to compare projects with } \\
\text { different risk level; } \\
\text { It allows investors to take into account the } \\
\text { environmental risk of the project; } \\
\text { It is pretty easy to apply; } \\
\text { It does not require significant costs for its use }\end{array}$ & $\begin{array}{l}\text { It is highly sensitive to the results of } \\
\text { calculations to estimate future cash flows; } \\
\text { Difficulties in determining the most effective } \\
\text { project }\end{array}$ \\
\hline PP & $\begin{array}{l}\text { It allows investors to take into account the } \\
\text { environmental risk of the project; } \\
\text { It is pretty easy to apply; } \\
\text { It does not require significant costs for its use }\end{array}$ & $\begin{array}{l}\text { Making a decision is likely to be a high level } \\
\text { of subjectivity; } \\
\text { It is inappropriate to compare alternative } \\
\text { projects in case of equal payback period and } \\
\text { different cash flows }\end{array}$ \\
\hline
\end{tabular}

Sources: own elaboration based on Klimenko (2011), Lipsits \& Kosov (1996).

The searches were done between April 2018 and April 2020 in online scientific databases. The first search was done in Web of Science using the keywords "investment analysis" and "innovation", which resulted in more than 5000 articles, thirty of which were relevant. This initial search showed limited published sources. We expanded our search beyond Web of Science to Google Scholar to include conference proceedings and other sources that may not be available in Web of Science. Further searches have been conducted using the keywords "assessment" or "innovation" and "efficiency" and a variety of keywords, some with wildcards. The keywords used were 1) "benefits", 2) "costs", 3) "risk", 4) "management", 5) "project", 6) "evaluation", 7) "economic damage*" and 8) "environmental damage*". Next, we searched for 9) "ecological damage" and "country risk," and lastly we searched for 10) "assessment" AND "innovative" and "project", but found no additional cases that completely met our criteria.

Finally, only 39 documents were included in the literature review. They were used to develop a scientific approach to environmental and economic investment project estimation based on risk assessment, including country risk adopted within the advanced innovative development concept.

\section{Theory development.}

The comprehensive literature review allowed to make the following theoretical proposition for future studies. 
In terms of the environmental impact of innovative projects, it is suggested to distinguish the following types:

- green projects (consistent with EU Environmental Policy and aimed at saving natural resources, conserving and cleaning up the environment);

- ecologically destructive ones (aimed at obtaining benefits by increasing consumption of natural resources and environmental pollution);

- ecologically neutral ones (aimed at conserving the environment without cleaning it up or any other positive changes);

- mixed ones (incorporating multidirectional consequences (results) for the environment at the stages of EEC).

Forming a business portfolio, the company should consider the fact that it is its structure that defines the level of its environmental safety (Domashenko et.al., 2017). The study of changes in the level of environmental safety (Prokopenko \& Shkola, 2012) has shown the need to form the company's business portfolio based on green innovations meeting UU Environmental policy and all market participants' interests to the greatest extent to avoid unnecessary costs, as well as EEC, extend.

The economic assessment of the environmental impact $(E)$ at the stages of EEC (Figure 1, Figure 2 ) is suggested to calculate by the formula:

$$
E=\sum_{i=1}^{6} \int_{0}^{T_{\text {RECE}}}\left(f_{\mathrm{i} 2}(t)-f_{\mathrm{i} 1}(t)\right) d t
$$

where:

$f_{i 1}(t)$ - ecological and economic flow, mon. units;

$f_{i 2}(t)$ - economic flow, mon. units;

$t$ - the current period of the project;

$T_{E E C r}$ length of the EEC;

$i$ - stages of EEC, $i \in[1 ; 6]$.

Figure 1. Flows of the innovative project at the stages of $\mathrm{EECl}$

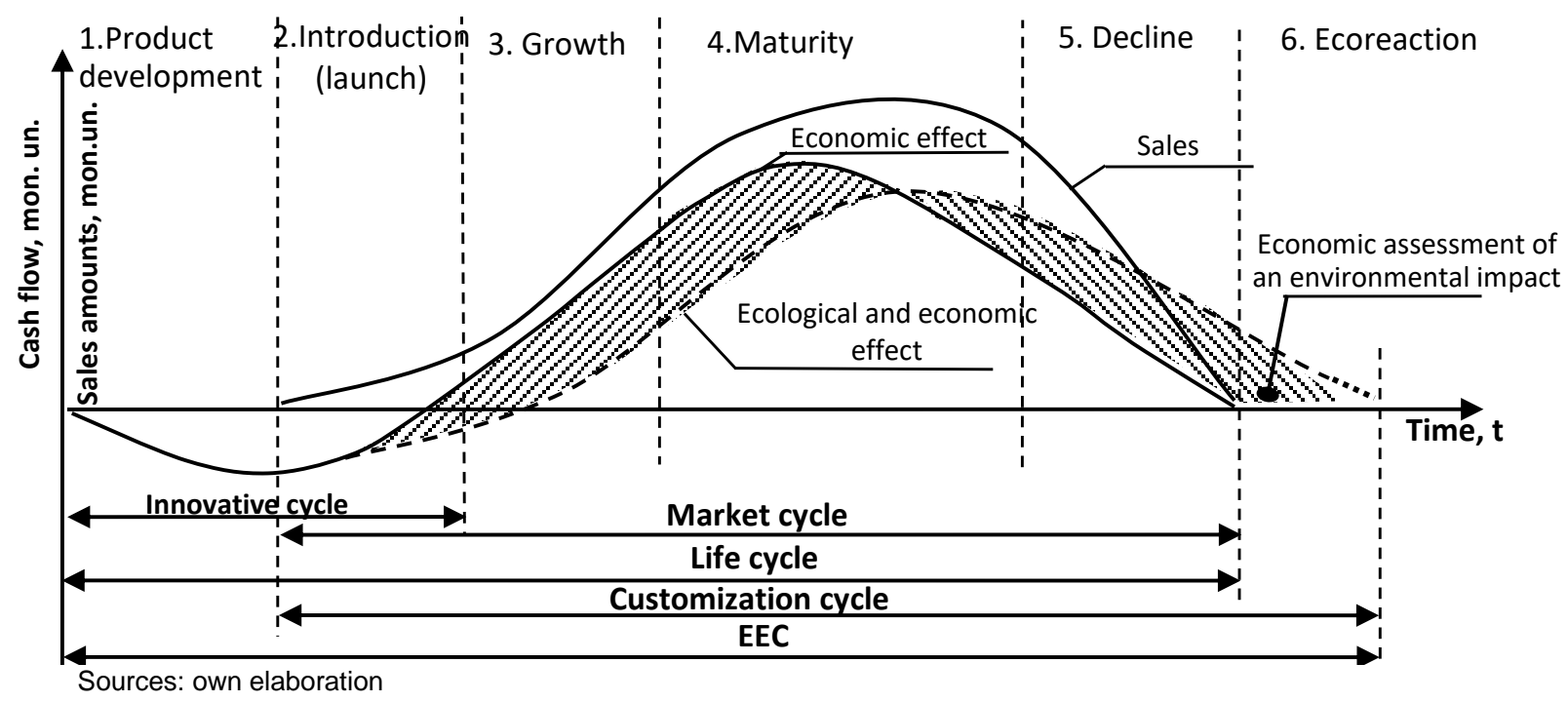


Figure 2. Stages to determine the sustainability index

Determining the ecological and economic indicators of project impact on environment

Comparing the indicators with the standards of environmental management

Analyzing the project quantitatively and qualitatively in terms of the environmental impact

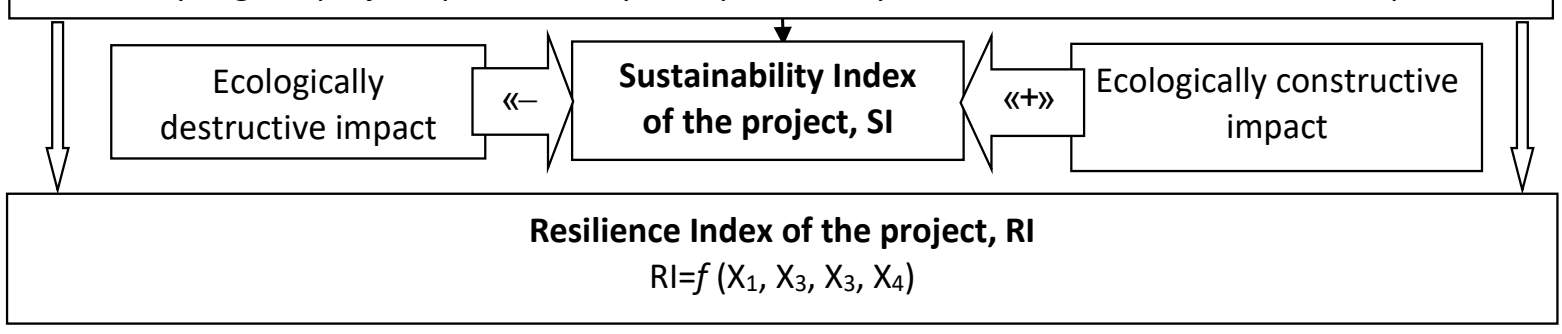

Sources: own elaboration

For prognostication of ecological and economic flows and economic flows the methods examined by Halynska \& Oliinyk (2020), Karaca \& Baleany (2020), Oliinyk et.al. (2018), Samonas (2015), Prokopenko and Rogkova (2011) is suggested to utilize.

It should be noted that not always do costs related to ensuring some result, and an expected effect concur. Furthermore, they are likely to be stretched in time. Therefore, in forecasting and valuing the expected financial flows, it is necessary to consider the speed of innovation process return through the time factor.

It should be noted that the basis for the project estimation is the forecast of EEC, including the life cycle of innovation (LCI) and the customization cycle of innovation (CCI) (Figure 1). The latter reflects an economic estimation of the ecological effect from creation, production, consumption of the innovation, and waste processing and reduction (Brauweiler et al., 2017; Furmaniak et. al., 2019) during its life cycle and after it leaves the market and consumption sphere.

The main types of destructive ecological impact have been explored in the paper (Prokopenko et. al., 2015). According to the authors' standpoint, a comprehensive measure of the environmental impact of the innovative project is its sustainability index, which is suggested to understand as a complex indicator incorporating the ecological characteristics of the environmental impact of innovation. The sustainability index shows the level of negative repercussions of the project and ecologically constructive changes in the environment. The main stages of determining the sustainability index are shown in Figure 2. While Beekaroo et. al. (2019) proposed to analyze 9 environmental, 4 economic and 2 social indicators, it is sensible to specify the list of impact indicators within the project framework.

Applying a system of ecological and economic indicators characterizing the repercussions (results) of the environmental impact makes it possible to control and eliminate deviations from the standard of environmental management in advance and decide on the innovative project. Relevant information on the environmental and economic components of the project is suggested to represent a combination of binary measures of the indicators of the ecological and economic indicators of the ecologically destructive impact. The sustainability index of the innovative project $(S I)$ is calculated as follows:

$$
\left\{\begin{array}{c}
S I=\sum_{k=1}^{6} \sum_{i=1}^{n} \sum_{j=1}^{4} b_{k i j} \\
b_{i j}=\left\{\begin{array}{l}
1, I_{i} \in\left[a_{i j} ; a_{i j+1}\right] \\
0, I_{i} \notin\left[a_{i j} ; a_{i j+1}\right.
\end{array}\right]
\end{array}\right.
$$


where:

$b_{k i j}$ - binary measures of the $i$ ecological and economic indicators of the ecologically destructive impact at the stage $k$ of EEC, $i \in[1 ; n], k \in[1 ; 6]$;

$i$ - an ordinal number of indicators (I) characterizing the factors of environmental impact, $i \in[1 ; \mathrm{n}]$;

$n$ - the total number of indicators / characterizing the factors of environmental impact;

$k$ - an ordinal number of the stage of EEC, $k \in[1 ; 6]$, namely Product Development (stage 1), Intriduction (Launch) (stage 2), Growth (stage 3), Maturity (stage 4), Decline (stage 5), Ecoreaction (stage 6);

$j$ - an ordinal number of the level of ecological destruction, $j \in[1 ; 4]$, namely Low (level 1), Below Average (level 2), Above Average (level 3), High (level 4);

$I$ - the indicator characterizing factors of environmental impact.

The level of the ecologically destructive impact of the innovative project is suggested to determine by Table 2.

Table 2. Identification of the level of project impact and the sustainability index

\begin{tabular}{|c|c|c|}
\hline Value range, $\mathbf{S I}$ & The level of impact & The sustainability index \\
\hline $\mathrm{SI}=4 \mathrm{n}$ & low & high \\
\hline $\mathrm{SI}=3 \mathrm{n}$ & below average & above average \\
\hline $\mathrm{SI}=2 \mathrm{n}$ & above average & below average \\
\hline $\mathrm{SI}=\mathrm{n}$ & high & low \\
\hline
\end{tabular}

Sources: own elaboration

As long as the preliminary project estimates the indicator $\mathrm{SI}=4 \mathrm{n}$, the project should be regarded as one that can be implemented. Other indicators of the project meet the conditions of the innovative project feasibility. Providing indicator $S \mid \neq 4 n$, the project should be abandoned.

As far as Figure 2 is concerned, resilience index (RI) is suggested to understand the project's ability to be long-term competitive in terms of technical requirements (given innovation as a technic system) and far-looking prospect on future EU Environment policy. Hence, for its evaluation, it is assumed to analyze four indicators, namely $X_{1}$ - correspondence with EU Environment policy; $X_{2}-$ stages of green innovation as a technical system; $X_{2}$ - enterprise; $X_{4}-$ stages of EEC (Figure 2) (in more detail see Shkola et al. (2021)).

For further ecological and economic justification of the innovative project, the algorithm to decide on its realization, based on additional criteria of integral risk $\left(R_{\text {total }}\right)$, the risk level $(K, K \in[0 ; \infty])$ and measures of project efficiency (NPV, IRR, $P I, P P)$ on the stages of EEC are suggested.

Types of innovative activity risks, including ecological risks and techniques of their evaluation, are examined in works (Kotenko et.al., 2020; Marsh\&McLennan, 2020). Also, it should be noted the necessity of taking into account a country's risk (Bouchet, M. H. et. al., 2003; Krayenbuehl, 1985; Krayenbuehl, 2001; Leavy, 1984) to resolve to embark on the project on the foreign market. The country risk $P_{n}$ is determined based on the Business Environmental Risk Index, calculated three times a year using the expert judgment estimation method. The structure of the analyzed parts of the indicator includes the efficiency of the economy, level of political risk, level of indebtedness, availability of bank loans, availability of short-term financing, availability of long-term loan capital, the likelihood of the occurrence of force majeure circumstances, the level of creditworthiness of the country, the amount of outstanding debt repayment obligations (Bouchet, M. H. et al.; 2003).

Estimation of the innovative project risk by stages of $\mathrm{EECl}$ is suggested to conduct by the formula 


$$
\left\{\begin{array}{c}
R_{\text {total }}=\sum_{i=1}^{6} R_{i} \rightarrow \min \\
R_{i}=\sum_{i=1}^{3} \sum_{j=1}^{9} \Delta \sigma_{i j} p_{i j} \\
R_{i}=\sum_{i=4}^{6} \sum_{j=2}^{10} \delta_{i j} p_{i j} \\
\sum p_{j}=1, \quad 0 \leq p_{i j} \leq 1
\end{array}\right.
$$

where:

$R_{\text {total }}$ - integral economic estimation of risk in project realization, mon. un.;

$p_{i j}$ - posterior certainty factor for the $i$-th type of risk at the $j$-th stage of EEC;

$R_{i}$ - the expected absolute value of loss from $i$-th risk type at $j$-th stage with pessimistic prognostication, mon. un., namely:

$R_{1}$ - expected absolute value of risk to lose revenues $\left(\Delta \sigma_{1 j}\right)$ due to delay in starting works over innovative cycle;

$R_{2}$ - expected absolute value of market risk;

$R_{3}$ - expected absolute value of risk to make an additional investment $\left(\Delta \sigma_{3 j}\right)$;

$\Delta \sigma_{1 j}$ - revenue loss due to delay in starting works at $j$-th stage of the innovative cycle, mon. un;

$\Delta \sigma_{2 j}$ - profit loss at the $j$-th stage of the market cycle due to market risk, mon. un.;

$\Delta \sigma_{3 j}$ - additional investment at the $j$-th stage of EEC, mon. un.;

$R_{4}$ - expected absolute value of environmental damage risk, followed by repercussions for the producer, mon. un.;

$R_{5}$ - expected absolute value of environmental damage risk, followed by repercussions for consumers, mon. un.;

$R_{6}$ - expected absolute value of environmental damage risk, followed by repercussions for society, mon. un.;

$\delta_{i j}$ - the value of environmental damage, followed by repercussions for the producer, consumers, society, mon. un.;

$j$ - an ordinal number of the stage of EEC, $j \in[1 ; 6]$, namely Product Development (stage 1), Intriduction (Launch) (stage 2), Growth (stage 3), Maturity (stage 4), Decline (stage 5), Ecoreaction (stage 6).

For initial estimation of economic reasonability to realize ecologically oriented innovative project considering risk, NPV method should be used, calculated for three prognostications (optimistic, pessimistic, the most likely one). For pessimistic prognostication, this index is suggested to calculate as follows

$$
N P V=\sum_{t=0}^{T_{E E C}}\left(\frac{E_{t}-I_{t}}{(1+r)^{t}}-R_{\text {total }}\right),
$$

where: 
$E_{t}$ - cash proceeds (financial flow) from the realization of the innovative project in the period $t$ (including economic estimation of ecologically constructive ("+"), ecologically destructive ("-") impact in the t-th period), mon. un.;

$I_{t}$ - investments into the project in the period $t$, mon. un.;

$r$ - interest rate, rel. un;

$t$ - the period of the project realization during EEC;

$T_{E E C I}$ - length of the EEC.

For the total estimation of the innovative project efficiency, the IRR calculation, $P I$ and $P P$ are carried out by techniques scrutinized by scholars Lipsits \& Kosov (1996). To make decisions, two scenarios for the innovation as a technical system are recommended to consider, namely Scenario 1 "Innovative Breakthrough" and Scenario 2 "Moral Aging".

In case of Scenario 1 "Innovative Breakthrough", at Introduction and Growth stages, it is advisable to proceed with the project if $E>0, K \leq 0,25, S I \in[3 n ; 4 n], P n \in[55 ; 100], E \rightarrow \max , I \rightarrow o p t$, $V \rightarrow$ max. Provided that just one of the conditions is not performed, it is wise to refuse the project.

In case of Scenario 2 "Moral aging", at the Product development stage if $K \leq 0,25, S I \in[3 n ; 4 n]$, it is advisable to continue the project. Suppose $K>0,25, S I \in[0 ; 3 n)$, the project is recommended to reject. At Introduction and Growth stages, if $E>0, K \leq 0,5, S I \in[3 \mathrm{n} ; 4 \mathrm{n}], E \rightarrow \max , \mathrm{Pn} \in[70 ; 100], l \rightarrow$ opt, $V \rightarrow \max$, the project is recommended to carry on. Provided that just one of the conditions is not performed, it is wise to turn down the project.

For both scenarios, at maturity state, the project is recommended to carry on providing $E>0$, $S / \in[3 n ; 4 n], P n \in[55 ; 100], E \rightarrow \max , N P V \rightarrow$ opt, $V \rightarrow \max$, one has. Otherwise, if just one of the conditions is not performed, the project is wise to reject.

\section{Conclusions.}

Thus, theoretical and methodic approach, improved by authors, to mange green projects within EU Environmental policy, based on forecasting EEC, analysis of sustainability and resilience, allows decision-makers to increase the assessment accuracy at starting stages, reduce risks of innovative projects and enhance of company's competitiveness, and, thereby, the ecological and economic security of stakeholders. As a result, it will extend existing knowledge about the green project assessment to strive for scientific excellence. It will fill a gap in the areas of advanced innovative development management.

Further research should be aimed at developing approaches to managing the advanced innovative development of a company considering its human capital and applying neural networks in maintaining intelligent management.

\section{Acknowledgment.}

The article came into being within the Grant no. 01200102003 entitled "Process of formation of the novel ecologically safe fertilizers with prolonged action based on the phosphorite deposits raw material" financed by the Ministry of Science and Education of Ukraine.

\section{References}

1. European Commision. (2019). The European Green Deal. Retrieved from https://eurlex.europa.eu/legal-content/EN/TXT/?qid=1596443911913\&uri=CELEX:52019DC0640\#document2

2. Andreeva, N. N. (2006). Ekologicheski orientirovannye investicii: vybor reshenij i upravlenie [Green Investment: Choice of Solutions and Management]. Odessa: IPREEI NAN Ukrainy [in Russian] 
3. Artyukhov, A., \& Artyukhova, N. (2018). Utilization of dust and ammonia from exhaust gases: New solutions for dryers with different types of the fluidized bed. Journal of Environmental Health Science and Engineering, 16(2), 193-204.

4. Artyukhov, A. E. Obodiak, V. K., Boiko, P. G., \& Rossi, P. C. (2017). Computer modeling of hydrodynamic and heat-mass transfer processes in the vortex type granulation devices. CEUR Workshop Proceedings, Vol. 1844, 33-47.

5. Artyukhov, A. E., \& Ivaniia A. V. (2017). Obtaining of porous ammonium nitrate in multistage and multifunctional vortex granulators. Scientific Bulletin of National Mining University, Vol. 6, 68-75.

6. Bouchet, M. H., Ephraim, C., and Bertrand, G. (2003). Country risk assessment. Chichester: Wiley.

7. Beekaroo, D., Callychurn, D.S., \& Hurreeram, D.K. (2019). Developing a sustainability index for Mauritian manufacturing companies. Ecological Indicators, 96, pp. 250-257.

8. Brauweiler, H.C., Shkola, V., \& Markova, O. (2017). Economic and legal mechanisms of waste management in Ukraine. Marketing and Management of Innovations, 2, 359-368. http://doi.org/10.21272/mmi.2017.2-33

9. Convention on Environmental Impact Assessment in a Transboundary Context (1991). New-York (USA); Geneva (Switzerland); United Nations. Retrieved from https://www.unece.org/fileadmin/DAM/env/eia/documents/legaltexts/Espoo_Convention_authe ntic_ENG.pdf

10.Dankeieva, O., Solomianiuk, N., Strashynska, L., Fiedotova, N., Soloviova, Y., \& Koval, V. (2021). Application of Cognitive Modelling for Operation Improvement of Retail Chain Management System. TEM Journal, 10(1), pp. 358-367.

11.Domashenko, M., Shkola V., Kuchmiyov A., \& Kotenko O. (2017). Innovative marketing strategies to provide ecological security (safety) at regional and global levels. Marketing and Management of Innovations, 4, 367-373. http://doi.org/10.21272/mmi.2017.4-33

12.Dzwigoł, H., Dźwigoł-Barosz, M., Zhyvko, Z., Miśkiewicz, R., \& Pushak, H. (2019). Evaluation of the Energy Security as a Component of National Security of the Country. Journal of Security and Sustainability Issues, 8(3), 307-317. http://doi.org/10.9770/jssi.2019.8.3(2)

13.Enríquez-de-Salamanca, Á., Díaz-Sierra, R., Martín-Aranda, R.M., \& Santos, M.J. (2017). Environmental impacts of climate change adaptation. Environmental Impact Assessment Review, 64, 87-96.

14.Furmaniak, S. et al. (2019). In silico study on the effects of carbonyl groups on chemical equilibrium of reactions with a polar product occurring under confinement in pores of activated carbons. Chemical Engineering https://doi.org/10.1080/00986445.2019.1700115

15.Gorgitano, M.T., \& Pirilli, M. (2016). Life cycle economic and environmental assessment for a greening agriculture. Quality - Access to Success, 17, 181-185.

16. Guo, L., Han, L., Hong, H., \& Zhou, T. (2018). Research on the enhancement effects of using ecological principles in managing the lifecycle of industrial land. Sustainability (Switzerland), 10(6), Article number 2076.

17. Halynska, Y, \& Oliinyk, V. (2020). Modeling of the Distribution Mechanism for Fuel Industry Enterprises' Rental Income in the System. State - Region - Enterprise. Journal of Advanced Research in Law and Economics, 11, 2(48), 370-381. https://doi.org/10.14505/jarle.v11.2(48).10.

18. Hutsaliuk, O., Koval, V., Tsimoshynska, O., Koval, M., \& Skyba, H. (2020). Risk Management of Forming Enterprises Integration Corporate Strategy. TEM Journal, 9(4), pp. 1514-1523.

19.Jay, M., \& Morad, M. (2020). A critical appraisal of the concept of ecological modernisation: A case study from New Zealand's dairy industry. MODSIM 2005 - International Congress on Modelling and Simulation: Advances and Applications for Management and Decision Making, Proceedings, 2428-2434. 
20.. A novel $\mathrm{R} / \mathrm{S}$ fractal analysis and wavelet entropy characterization approach for robust forecasting based on self-similar time series modeling. Fractals, 28, 8, 2040032. doi: $10.1142 / \mathrm{S} 0218348 \times 20400320$

21.Klimenko, O. V. (2011). Ecological-economic justification of investment activity of an industrial enterprise. (Candidate's thesis).

22.Kotenko O., Shkola V., Domashenko M., Kasianenko T., \& Khomutenko L. (2020). Anti-crisis management of international investments in energy-efficient, resource-saving and clean technologies. International Journal of Ecological Economics and Statistics, 41 (4). Retrieved from http://www.ceser.in/ceserp/index.php/ijees/article/view/6627

23.Koval, V., Mikhno, I., Trokhymets, O., Kustrich, L., \& Vdovenko, N. (2020). Modeling the interaction between environment and the economy considering the impact on ecosystem. E3S Web of Conferences, 166, 13002.

24.Krayenbuehl, T. E. (1985). Country Risk Assessment and Monitoring. Cambridge: WoodheadFaulkner.

25.Krayenbuehl, T. (2001). Cross-border exposures and Country Risk Assessment and Monitoring. Cambridge: Woodhead Publishing Ltd.

26.Kurbatova, T. (2018). Economic benefits for producers of biogas from cattle manure within energy co-operatives in Ukraine. International Journal of Sustainable Energy Planning and Management, 18, 69-80. https://doi.org/10.5278/ijsepm.2018.18.5

27.Kurbatova, T., \& Khlyap, H. (2015). GHG emissions and economic measures for low carbon growth in Ukraine. Carbon Management, 6 (1-2), https://doi.org/10.1080/ 17583004.2015.1065376.

28.Kuzior, A.; Kwilinski, A.; Tkachenko, V. (2019). Sustainable Development of Organizations Based on the Combinatorial Model of Artificial Intelligence. Entrepreneurship and Sustainability, 7(2), 13531376. http://doi.org/10.9770/jesi.2019.7.2(39)

29.Kwilinski, A., Ruzhytskyi, I., Patlachuk, V., Patlachuk, O., \& Kaminska, B. (2019). Environmental Taxes as a Condition of Business Responsibility in the Conditions of Sustainable Development. Journal of Legal, Ethical and Regulatory Issues, 22(SI2) 1544-0044-22-SI-2-354: 1-6. Retrieved from https://www.abacademies.org/articles/Environmental-taxes-as-a-condition-ofbusiness-responsibility-in-the-conditions-of-sustainable-development-1544-0044-22-SI-2-354.pdf

30.Leavy, B. (1984). Assessing Country Risk for Foreign Investment Decisions. Long Range Planning, Vol. 17, № 3.

31.Li, H., Deng, Q., Zhang, J., Olanipekun, A.O., \& Lyu, S. (2019). Environmental impact assessment of transportation infrastructure in the life cycle: Case study of a fast track transportation project in China. Energies, 12(6), Article number en12061015.

32.Lipsits, I. V., \& Kosov, V. V. (1996). Investicionnyj proekt: metody podgotovki i analiza [Investment project: methods of preparation and analysis]. Moskow: Publishing-house BEK [in Russian].

33.Li, Z., \& Ohkubo, T. (2016). Environmental impact assessment methodology of concrete. Journal of Structural and Construction Engineering, 81(720), pp. 199-209.

34.Linde, M., Attard, R., \& Wilson, C. (2013). Undervaluing positive impacts in the environmental impact assessment process. Coasts and Ports, pp. 23-28.

35.Liu, J.-L. (2012). Study on cycle economic and ecological innovation system under the perspective of ecological capital. 1st International Conference on Energy and Environmental Protection, ICEEP 2012, 524-527, pp. 3584-3588. https://doi.org/10.4028/www.scientific.net/AMR.524-527.3584

36.Luo, Y., Wang, Z., Chen, Y., \& Liao, Z. (2017). Research on assessing eco-cycle industry chain of mineral resources from the perspective of innovation-driven. Journal of Mines, Metals and Fuels, 65(3), pp. 91-100. 
37.Marsh\&McLennan and Zurich Insurance Grope. (2020). The global risks report 2020. Insight Report. $15^{\text {th }} \quad$ Edition. Retrieved from http://www3.weforum.org/docs/WEF_Global_Risk_Report_2020.pdf

38. Mayer, F., Bhandari, R., \& Gäth, S. (2019). Critical review on life cycle assessment of conventional and innovative waste-to-energy technologies. Science of the Total Environment, 672, pp. 708-721.

39.Mikhno, I., Koval, V., Shvets, G., Garmatiuk, O., \& Tamošiūnienè, R. (2021). Green Economy In Sustainable Development And Improvement Of Resource Efficiency. Central European Business Review, 10(1), pp. 99-113.

40.Miśkiewicz, R, \& Wolniak, R. (2020). Practical Application of the Industry 4.0 Concept in a Steel Company. Sustainability, 12(14), 5776. https://doi.org/10.3390/su12145776

41.Motta, W.H., Issberner, L.-R., \& Prado, P. (2018). Life cycle assessment and eco-innovations: What kind of convergence is possible? Journal of Cleaner Production, 187, pp. 1103-1114.

42.Mura, L., Buleca, J.,Hajduova, Z., \& Andrejkovic, M. (2015). Quantitative financial analysis of small and medium food enterprises in a developing country. Transformations in Business and Economics, 14(1), pp. 212-224.

43.Oliinyk, V., Wiebe, I., Syniavska O., Yatsenko, V. (2018). Optimization model of Bass. Journal of Applied Economic Sciences. Volume XIII, Winter, 8(62), 2168- 2183.

44.Omelyanenko, V., Kudrina, O., Semenikhina, O., Zihunov, V., Danilova, O., \& Liskovetska, T. (2020). Conceptual aspects of modern innovation policy. European Journal of Sustainable Development, 9(2), 238. https://doi.org/10.14207/ejsd.2020.v9n2p238

45.Popova, O. Yu., \& Safyants, O. S. (2013). Content of the scope of the companies' business efficiency controlling. Marketing and Management of Innovations, 4, 228-235.

46.Prokopenko, O.V. (2011a). Consumer choice types in marketing of ecological innovations. Actual Problems of Economics, 16(2), pp. 109-116.

47.Prokopenko, O.V., \& Rogkova, E.Yu. (2011). The modeling of the innovation market in the government stimulation system of its ecologization. Marketing and Management of Innovations, 3(1), pp. 91-98.

48.Prokopenko, O.V., Shkola, V.Y., Domashenko, M.D., \& Prokopenko, M.O. (2015). Conceptual grounds to form motivational constituent of the international ecological policy. Marketing and Management of Innovation, 4, 245-259. http://mmi.fem.sumdu.edu.ua/en/journals/2015/4/245259

49.Prokopenko, O. V., \& Shkola, V. Yu. (2012). Controlling of the ecological and economic enterprise security on the bases of ecomarketing. Marketing and Management of Innovations, 4, 337-346. http://mmi.fem.sumdu.edu.ua/en/journals/2012/4/337-346

50.Prokopenko, O.V. (2011b). The motivational mechanism of innovative development: components and the condition of its market structure. Marketing and Management of Innovations, 1, pp. 167175.

51.Samonas, M. (2015). Financial Forecasting, Analysis, and Modelling: A Framework for Long-Term Forecasting. John Wiley \& Songs LTD. https://doi.org/10.1002/9781118921111.ch3

52.Shkola V., Olshanska O., Kasyanenko T., \& Domashenko M. (2021). Management of enterprise's advanced development for its international competitiveness. In: Elhoseny, M., Yuan, X., Krit, S. (Eds.), Distributed Sensing and Intelligent SystemsDistributed Sensing and Intelligent Systems. Proceedings of ICDSIS 2020, Springer, https://doi.org/10.1007/978-3-030-64258-7 https://www.springer.com/gp/book/9783030642570\#aboutAuthors

53.Shkola, V. Y., \& Shcherbachenko, V. A. (2011). Economic justification of the role of intellectual capital in the sphere of innovative economic system. Marketing and Management of Innovations. 2011. Issue 3 (1). Page 72-78 http://mmi.fem.sumdu.edu.ua/en/journals/2011/3_1/72-78 
54.Tanashchuk, E.A., Kovtunenko, K.V., Kovtunenko, Yu.V. (2018). Theoretical and methodical principles of capital structure management in the innovation activity of telecommunication operators. Journal of Automation and Information Sciences, 50(3), pp. 71-84. 